\title{
Effect of chronic treatment with Rosiglitazone on Leydig cell steroidogenesis in rats: In vivo and ex vivo studies
}

\author{
Janaína A Couto ${ }^{1}$, Karina LA Saraiva ${ }^{2}$, Cleiton D Barros ${ }^{3}$, Daniel P Udrisar ${ }^{4}$, Christina A Peixoto ${ }^{2}$, \\ Juliany SB César Vieira ${ }^{4}$, Maria C Lima ${ }^{3}$, Suely L Galdino ${ }^{3}$, Ivan R Pitta ${ }^{3}$, Maria I Wanderley ${ }^{4^{*}}$
}

\begin{abstract}
Background: The present study was designed to examine the effect of chronic treatment with rosiglitazone thiazolidinedione used in the treatment of type 2 diabetes mellitus for its insulin sensitizing effects - on the Leydig cell steroidogenic capacity and expression of the steroidogenic acute regulatory protein (StAR) and cholesterol side-chain cleavage enzyme (P450scc) in normal adult rats.

Methods: Twelve adult male Wistar rats were treated with rosiglitazone $(5 \mathrm{mg} / \mathrm{kg})$ administered by gavage for 15 days. Twelve control animals were treated with the vehicle. The ability of rosiglitazone to directly affect the production of testosterone by Leydig cells ex vivo was evaluated using isolated Leydig cells from rosiglitazonetreated rats. Testosterone production was induced either by activators of the CAMP/PKA pathway (hCG and dbcAMP) or substrates of steroidogenesis [22(R)-hydroxy-cholesterol (22(R)-OH-C), which is a substrate for the P450scc enzyme, and pregnenolone, which is the product of the P450scc-catalyzed step]. Testosterone in plasma and in incubation medium was measured by radioimmunoassay. The StAR and P450scc expression was detected by immunocytochemistry.
\end{abstract}

Results: The levels of total circulating testosterone were not altered by rosiglitazone treatment. A decrease in basal or induced testosterone production occurred in the Leydig cells of rosiglitazone-treated rats. The ultrastructural and immunocytochemical analysis of Leydig cells from rosiglitazone-treated rats revealed cells with characteristics of increased activity as well as increased StAR and P450scc expression, which are key proteins in androgen biosynthesis. However, a number of rosiglitazone-treated cells exhibited significant mitochondrial damage.

Conclusion: The results revealed that the Leydig cells from rosiglitazone-treated rats showed significant reduction in testosterone production under basal, hCG/dbcAMP- or 22 (R)-OH-C/pregnenolone-induced conditions, although increased labeling of StAR and P450scc was detected in these cells by immunocytochemistry. The ultrastructural study suggested that the lower levels of testosterone produced by these cells could be due to mitochondrial damage induced by rosiglitazone.

\section{Background}

Rosiglitazone is a PPAR $\gamma$ synthetic activator from the group of thiazolidinediones (TZDs) often used in the treatment of chronic diseases such as type 2 diabetes and other forms of insulin resistance, as seen in polycystic ovary syndrome (PCOS). Activation of PPAR $\gamma$ by TZDs improves insulin sensitivity and, consequently,

\footnotetext{
* Correspondence: ineswanderley@gmail.com
${ }^{4}$ Department of Physiology and Pharmacology, Universidade Federal de

* Correspondence: ineswanderley@gmail.com
${ }^{4}$ Department of Physiology and Pharmacology, Universidade Federal de Pernambuco, Recife, 50.670-901, Brazil
}

bodily glycemia and lipid control and reduces the concentration of plasma androgen in patients with PCOS [1-5]. Besides their well-known effects on insulin sensitivity and energy metabolism, TZDs have also been reported to modulate steroid production in gonad tissues. For example, TZDs stimulate progesterone secretion in MA-10 Leydig tumor cells [6,7] and ovarian cells [8]. Opposing effects of TZDs on androgen levels and/ or production in male humans [9-11] and animal models have been described [7,12-20]. An inhibitory effect of 
rosiglitazone on the production of testosterone has been demonstrated in healthy men [11], while in obese male Zucker rats [19] plasma testosterone was not affected by this TZD. TZDs have also been reported to directly inhibit steroidogenic enzymes and steroid secretion in vitro, as evidenced by a decrease in the activity of $17 \alpha$ hydroxylase, 17,20-lyase, aromatase and $3 \beta$-hydroxysteroid dehydrogenase [7,12-18]. Although there is evidence of the modulation of testosterone action and/or production by TZDs, the effects of oral rosiglitazone treatment on circulating plasma testosterone and/or production have not been reported in experimental animal models.

The aim of the present study was to determine whether oral rosiglitazone treatment influences testicular production of testosterone using an ex-vivo model of Leydig cells isolated from rosiglitazone-treated adult male rats. Ultrastructural and immunocytochemical analysis of Leydig cell was performed to assess the cellular integrity and the expression of StAR and P450scc, which are key proteins in androgen biosynthesis.

\section{Methods}

\section{Animals and experimental procedures}

Twelve male Wistar-Albino rats (aged 8-9 weeks and weighing 200-250 g) were used and obtained from the Bioterium of the Department of Antibiotics, Universidade Federal de Pernambuco, Brazil. The rats were kept in a small colony in the animal house at a temperature of $22 \pm 3^{\circ} \mathrm{C}$, with a 12:12 hour light/dark cycle, receiving standard feed (Purina ${ }^{\circ}$ ) and water as required. The experimental procedure was approved by the local Ethics Committee for Animal Experimentation. The rats were randomly divided into two groups of six animals each. The test group received rosiglitazon (GlaxoSmithKline, Aranda de Duero, Spain) prepared using 1\% (v/v) Tween-80 (Sigma Chemical Co., St. Louis, MO, USA) and administered daily via oral gavage at $5 \mathrm{mg} /$ $\mathrm{kg} / \mathrm{d}$. The control group received $1 \%$ vehicle. Both groups were treated for 15 consecutive days. After treatment, the rats were sacrificed with carbon dioxide. Following decapitation, truncal blood was collected in heparinized tubes and kept on ice until the plasma was obtained by centrifugation $\left(600 \times \mathrm{g}, 15 \mathrm{~min} .6^{\circ} \mathrm{C}\right)$. The plasma was aliquoted and stored at $-20^{\circ} \mathrm{C}$ until analysis for testosterone concentration. The testes and seminal vesicles were removed and weighed. The testes were used for ex vivo assays and morphological analysis. The dry weight of the seminal vesicles was determined by drying these tissues in an oven overnight at $110^{\circ} \mathrm{C}$.

\section{Ex vivo study}

For the ex vivo study, the testes from rosiglitazone-treated or control rats were decapsulated and the Leydig cells were isolated and purified as described in Wanderley and Negro-Vilar [21], with slight modifications. Briefly, the decapsulated testes were incubated in an enzyme solution of $0.5 \mathrm{mg} / \mathrm{ml}$ collagenase (Sigma), $0.2 \mathrm{mg} / \mathrm{ml}$ soybean trypsin inhibitor (Sigma) and $5 \mu \mathrm{g} / \mathrm{ml}$ leupeptin (Sigma) in PBS $\left(136.9 \mathrm{mM} \mathrm{NaCl}, 2.68 \mathrm{mM} \mathrm{KCl}, 8.1 \mathrm{mM} \mathrm{Na}_{2} \mathrm{H}-\right.$ $\mathrm{PO}_{4} .7 \mathrm{H} 2 \mathrm{O}, 1.47 \mathrm{mM} \mathrm{KH}{ }_{2} \mathrm{PO}_{4}$ ) containing $0.1 \%$ bovine serum albumin (PBS/BSA) (BSA, fraction V, ICN Biomedical, California, CA, USA), $\mathrm{pH}$ 7.4, in a shaking water bath $\left(20 \mathrm{~min}, 90 \mathrm{~Hz}, 34^{\circ} \mathrm{C}\right)$. The dispersed testes were suspended in $50 \mathrm{ml}$ (final volume) PBS/BSA and the dissociated tubules were allowed to settle $(5 \mathrm{~min})$. The supernatant was filtered and washed with $5 \mathrm{ml}$ PBS/BSA. The filtered cell suspension was centrifuged $(150 \times \mathrm{g}, 15$ $\mathrm{min}, 20^{\circ} \mathrm{C}$ ). The pellet was re-suspended in $5 \mathrm{ml} \mathrm{PBS} / \mathrm{BSA}$, loaded onto the top of a discontinuous Percoll (HE Healthcare Bio-Sciences AB, Uppsala, Sweden) density gradient $(20 \%, 35 \%, 43 \%, 68 \%$ and $90 \%)$ and centrifuged at $800 \times \mathrm{g}$ for $30 \mathrm{~min}$ at $20^{\circ} \mathrm{C}$. Cells in the $43-68 \%$ interface (specific gravity: $1.0640-1.0960 \mathrm{~g} / \mathrm{ml}$ ) were collected, washed twice with medium 199 (M199) (Gibco, Grand Island, NY, USA) containing 0.1\% BSA, re-suspended in M199/0.1\% BSA and used immediately for the experiments. Cells $\left(0.3 \times 10^{6}\right.$ cells $\left./ 0.5 \mathrm{ml}\right)$ were treated (incubated) for $2 \mathrm{~h}$ with M199 (basal testosterone), hCG (Sigma) $(1 \mathrm{mIU} / \mathrm{ml})$, dbcAMP (Sigma) $(1 \mathrm{mM}), 22$-hydroxycholesterol (Sigma) $(10 \mu \mathrm{M})$ or pregnenolone (Sigma) $(1$ $\mu \mathrm{M})$ (stimulated/induced testosterone) in a shaking water bath $\left(60 \mathrm{~Hz}, 34^{\circ} \mathrm{C}\right)$ in an atmosphere of $95 \% \mathrm{O}_{2}$ and $5 \%$ $\mathrm{CO}_{2}$. At the end of incubation, the cells were centrifuged. The supernatant was collected and stored at $-20^{\circ} \mathrm{C}$ until testosterone measurement by radioimmunoassay (RIA). To assess the effects of chronic treatment with rosiglitazone on cell viability the trypan blue exclusion was used. The trypan blue exclusion is widely used screening method to measure plasma membrane integrity. The trypan blue assay was performed after the period of $2 \mathrm{~h}$ incubation of cells. Cells were incubated with trypan blue $(0,5 \%)$ for $20 \mathrm{~min}$ and the percentage of blue cells, indicating a capture of the colorant due to plasma membrane rupture, were counted. $90-95 \%$ of no colored cells was considered normal cell viability.

\section{Light microscopy}

The testes were fixed in Bouin's solution for eight hours, then dehydrated in an alcohol series and embedded in paraffin wax. Serial sections of $4 \mu \mathrm{m}$ were cut with a microtome (Leica RM 3125RT) and stained with hematoxylin-eosin for histological analysis [22].

\section{Electron transmission microscopy}

For routines procedures, the fragments of testes were fixed overnight in a solution containing $2.5 \%$ glutaraldehyde (Sigma) and 4\% paraformaldehyde (Sigma) in 0.1 $M$ cacodylate (Sigma) buffer. After fixation, the samples were washed twice in the same buffer and post-fixed in a solution containing $1 \%$ osmium tetroxide (Sigma), 2 $\mathrm{mM}$ calcium chloride and $0.8 \%$ potassium ferricyanide 
in 0.1 cacodylate buffer, $\mathrm{pH} 7.2$, dehydrated in acetone and embedded in SPIN-PON resin (Embed 812). Polymerization was performed at $60^{\circ} \mathrm{C}$ for three days [23]. Ultrathin sections were collected on 300-mesh nickel grids, counterstained with 5\% uranyl acetate and lead citrate and examined with a FEI Morgani 268D transmission electron microscope. For the immunocytochemical study, the isolated and hCG-stimulated Leydig cells were fixed overnight in a solution containing $0.5 \%$ glutaraldehyde and $4 \%$ paraformaldehyde in $0.1 \mathrm{M}$ phosphate buffer. After fixation, the samples were washed three times in the same buffer, incubated with $50 \mathrm{mM}$ ammonium chloride for $40 \mathrm{~min}$, dehydrated in alcohol and embedded in LR-White resin (Electron Microscopy Science, Washington, PA, USA). Polymerization was performed at $30^{\circ} \mathrm{C}$ for five days. This procedure was carried out as described by Peixoto et al. [24].

\section{Immunocytochemistry}

Ultrathin sections of isolated and hCG-stimulated Leydig cells were cut with a diamond knife, collected on nickel grids and incubated for $30 \mathrm{~min}$. at room temperature in $0.02 \mathrm{M}$ PBS, pH 7.2, containing 1\% BSA and 0.1\% Tween 20 (PBS-BT). The sections were then incubated for one hour with primary antibodies against StAR and P450scc at dilutions of 1:25 and 1:200, respectively, in PBS-BT. The sections were then washed in PBS-BT and incubated with a secondary antibody, $10 \mathrm{~nm}$ colloidal gold-labeled goat anti-rabbit IgG. As an antibody control, sections were incubated only in the presence of the gold-labeled marker. Following the immunostaining procedures, the sections were counterstained with $5 \%$ uranyl acetate and lead citrate [24]. Quantitative analysis was performed on photomicrographs at a final magnification of 28 '000× of 10 different Leydig cells, showing the entire profile and randomly chosen, in order to compare the number of gold-labeled particles in the control and rosiglitazone-treated cells using the Student's $t$ test. Since the experimentally treated cells and control samples were processed in an identical method, no correction for tissue shrinkage was performed.

\section{Antibodies}

The polyclonal antibodies StAR (sc-25806, Santa Cruz Biotechnology, INC., Santa Cruz, CA, USA) and cytochrome P450scc enzyme (AB1244, Chemicon International, Inc., Canada) were raised in rabbits against different peptides corresponding to amino acids 1-285 representing full-length StAR of human origin and amino acids $421-441$ of the rat cytochrome P450scc enzyme, respectively. The 10-nm colloidal gold-labeled goat anti-rabbit IgG was purchased from Sigma Chemical Co. (St. Louis, MO, USA).

\section{Radioimmunoassay and statistical analysis}

Testosterone was measured in plasma (with extraction) and directly (without extraction) in the incubation medium by a charcoal-dextran RIA [25] that employs $\left[{ }^{3} \mathrm{H}\right]$-testosterone as a tracer and primary antiserum raised in rabbits in our laboratory against testosterone3-(0-carboxymethyl)oxime:BSA. Intra-assay and interassay coefficients of variation were $8.1 \%$ and $15.1 \%$, respectively. The testosterone antibody demonstrated < $0.1 \%$ cross-reactivity with androstenedione, dehydroepiandrosterone, androsterone, $17 \alpha$-hydroxyprogesterone, $\beta$-estradiol and estrone. None of the substances tested interfered with the assays. The data from the different analyses are expressed as the mean \pm SEM of six replicates determinations for plasma and triplicate determinations for incubation medium and were representative of results obtained in at least two similar experiments. The Student's $t$ test, one-way analysis of variance (ANOVA) and Dunnett's test were used to determine differences between control and rosiglitazone-treated plasma and cells, respectively. P-values less than 0.05 were considered statistically significant.

\section{Results}

Body weight, testis weight, seminal vesicle weight and plasma testosterone

The treatment of rats with rosiglitazone did not induce changes in body weight or the relative weight of the testes or dried seminal vesicles (data not shown). Total plasma testosterone was not significantly modified by the treatment with rosiglitazone (control: $25.01 \pm 3.5$; rosiglitazone: $38.4 \pm 7.0 \mathrm{ng} / \mathrm{ml}$ ), which may explain the unaltered weight of the seminal vesicles, since it is known that testosterone supports the trophism of this organ.

\section{Ex vivo testosterone secretion}

These experiments examined the impact of chronic treatment with rosiglitazone on the steroidogenic response of Leydig cells to direct induction by activators of the cAMP/PKA pathway (hCG and dbcAMP), which is the major signaling pathway regulating steroidogenesis [26], and by substrates of steroidogenesis (22-OH-C and pregnenolone). The objective of the use of these substrates was to determine whether the limiting-steps of steroidogenesis - the transportation of cholesterol from outer to inner mitochondrial membrane by the StAR protein and the cleavage of the cholesterol side chain by mitochondrial P450scc to yield pregnenolone - were affected by rosiglitazone treatment. Rosiglitazone treatment modified the steroidogenic response, resulting in a decrease in testosterone production under basal, hCG/ dbcAMP- or 22 (R)-OH-C/pregnenolone-induced conditions (Figure 1). This reduced steroidogenic response to stimulators/inducers of testosterone production can be seen by the reduction in the magnitude of the stimulation/induction obtained in both the control and rosiglitazone-treated groups. The increase in testosterone 
production induced by hCG and dbcAMP in cells from control rats was 24.1-fold $( \pm 1.2)$ and 22.9 -fold $( \pm 5.5)$, respectively, whereas the increase in production in cells from rosiglitazone-treated rats was 12.4 -fold $( \pm 0.4)$ and 10.5 -fold $( \pm 0.2)$, respectively. Similarly, the increase in testosterone production induced by $22(\mathrm{R})-\mathrm{OH}-\mathrm{C}$ and pregnenolone in cells from control rats was 77.0-fold $( \pm$ 33.0) and 34.4-fold ( \pm 0.9 ), respectively, whereas the increase in production in cells from rosiglitazone-treated rats was 46.0-fold ( \pm 39.3 ) and 35.4-fold ( \pm 20.2 ), respectively. These results indicate that the rosiglitazone treatment decreases the function of multiple steroidogenic enzymes, including P450scc. In order to evaluate whether the inhibitory effect of the chronic treatment with rosiglitazone on testosterone production was due to a decrease in cell viability, the trypan blue exclusion assay was used. This test demonstrated that inhibition was not due to the toxicity of rosiglitazone per se, as the percentages of integral cells obtained after $2 \mathrm{~h}$ of incubation were comparable between the cells from rosiglitazone-treated (93\%) and from controls (95\%) rats.

\section{Histological analysis}

No morphological differences were found in Leydig cells between the control and experimental groups (data not shown).

\section{Electron microscopy analysis}

The morphological characteristics of control Leydig cells were an irregular polygonal shape with an asymmetrical nucleus located eccentrically in the cell body. The filopodia were protruded and interdigitated with the filopodia from opposite cells. The tubular smooth endoplasmic reticulum (SER) was abundant, consisting of interconnected, branched and anastomosing tubules throughout the cytoplasm. This tubular SER was occasionally surrounding mitochondria and lipid droplets. The rough endoplasmic reticulum (RER) was scarce, located mainly in perinuclear and peripheral regions. Mitochondria of variable size and with tubular and thick cristae were numerous and scattered throughout the cytoplasm. Several Golgi complexes were dispersed in the cell body, often found near a cell pole, since the nucleus is eccentrically located. Peroxisomes of irregular sizes were identified in portions of the cytoplasm (Figure 2:A). Rosiglitazone-treated Leydig cells presented all the organelles cited above. However, some differences were observed, such as a vesicular SER, consisting of separated vesicles of variable diameters and dilated Golgi complexes, which are typical alterations of an activated steroidogenic cell. However, several Leydig cells exhibited enlarged, vacuolated mitochondria with disarranged or discontinuous cristae (Figure 2:B and 2:C).

\section{StAR and P450scc in Leydig cells}

Immunocytochemistry revealed that the enzymatic steroidogenic pathway was significantly more active in the Leydig cells treated with rosiglitazone. More evident StAR and P450scc labeling was detected throughout the cytoplasm of treated cells in comparison to control samples (Figures 3 and 4).

\section{Discussion}

Thiazolidinediones (TZDs) are frequently administered to patients with insulin resistance associated with type II diabetes [for a review, see [27-29]]. Moreover, there is growing evidence that the biological effects of TDZs go

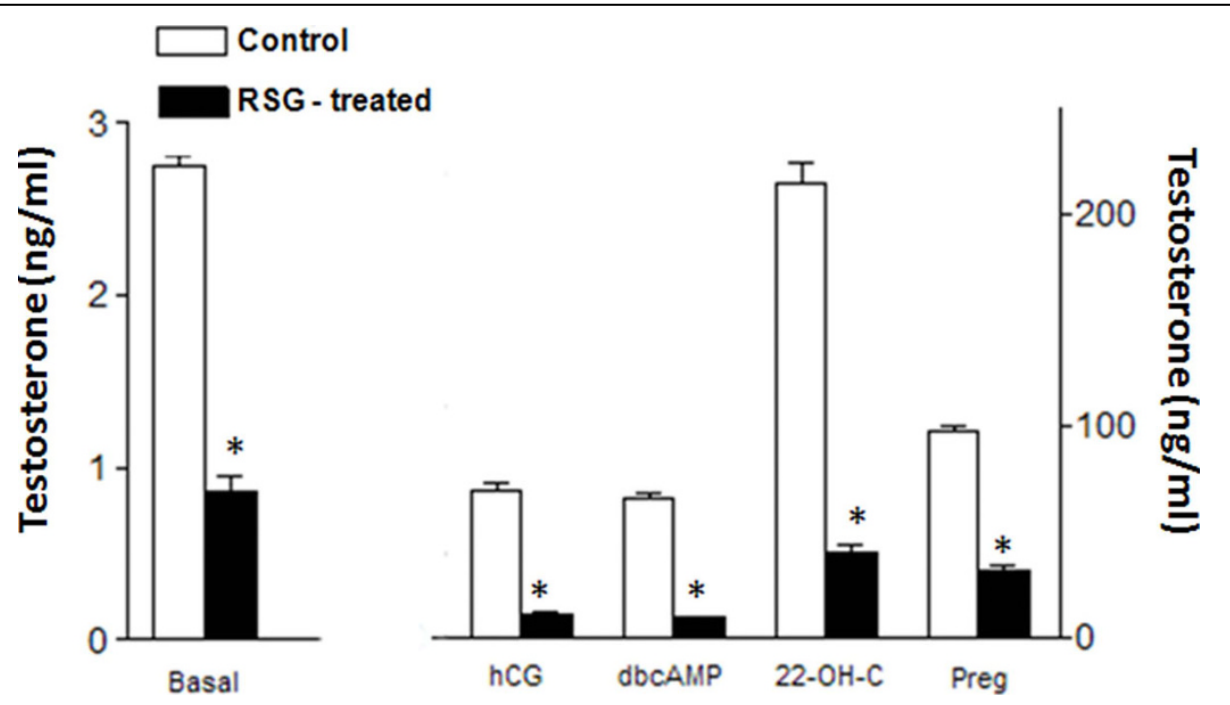

Figure 1 Ex vivo production of testosterone in Leydig cells isolated from control or rosiglitazone-treated (RSG-treated) rats; Leydig cells $\left(0.3 \times 10^{6} / 0.5 \mathrm{ml}\right)$ were incubated for $2 \mathrm{~h}$ with M199, hCG $(1 \mathrm{mlU} / \mathrm{ml})$, dbcAMP $(1 \mathrm{mM}), 22-\mathrm{OH}-\mathrm{C}(10 \mu \mathrm{M})$ or pregnenolone $(1$ $\mu \mathrm{M})$. Results are the mean \pm SEM of three determinations; ${ }^{*} \mathrm{p}<0.001$ (ANOVA). 


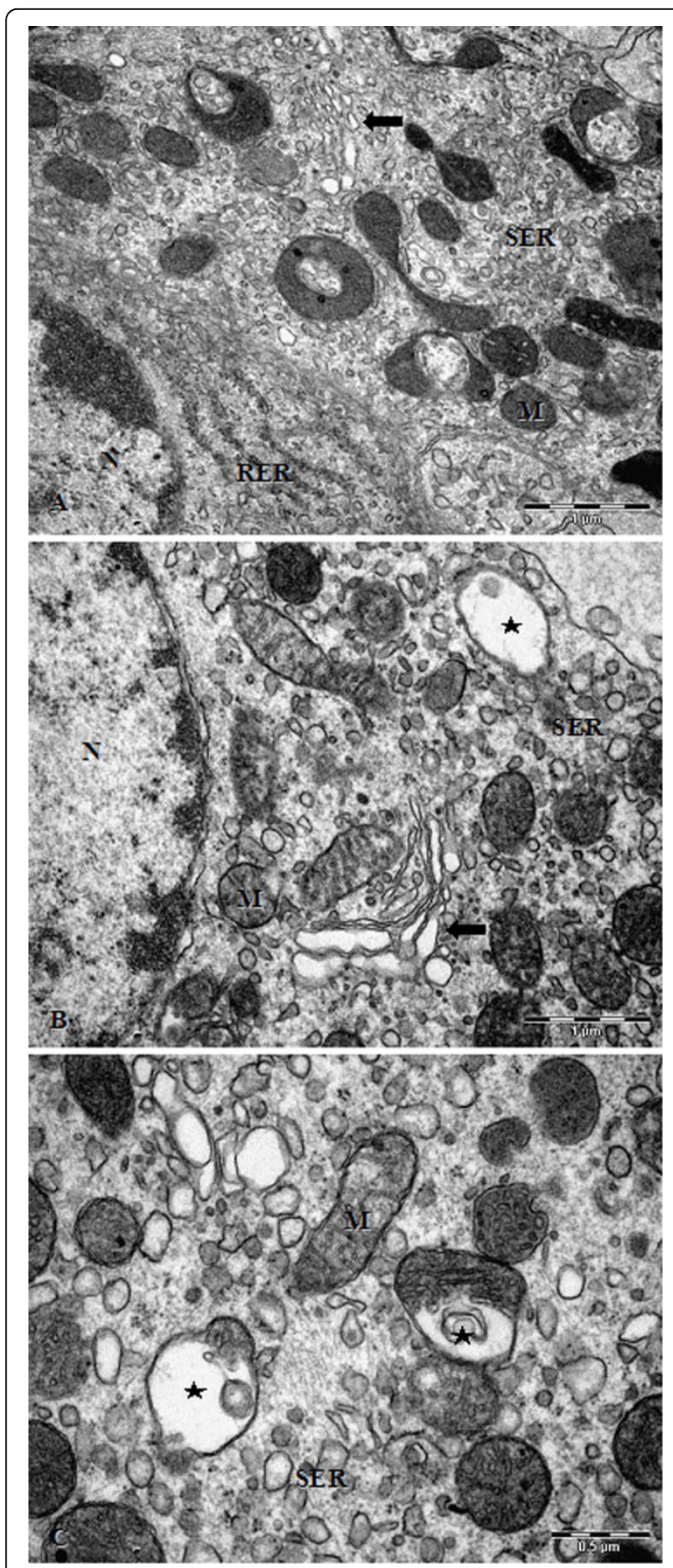

Figure 2 Testis Leydig Cells; A - Untreated Leydig cells with nucleus, Golgi complex (arrows), SER, RER and mitochondria; Bar $1 \mu \mathrm{m}$; B and C - Leydig cells treated with rosiglitazone showing dilated and vacuolated mitochondria (star), vesicular smooth endoplasmic reticulum and dilated Golgi complex (arrows); Bars $1 \mu \mathrm{m}$ and $0.5 \mu \mathrm{m}$, respectively; M, mitochondria; $\mathrm{N}$, nucleus; RER, rough endoplasmic reticulum; SER, smooth endoplasmic reticulum. beyond insulin-sensitizing [30]. It has been demonstrated that TDZs have a considerable impact on the production and metabolism of gonad hormones [6,8,14,17-20]. Rosiglitazone and other thiazolidinediones are known to affect testosterone production in humans $[10,11,31]$. However, effects of rosiglitazone on testosterone level and synthesis have not been reported in experimental animal models. Therefore, the present study investigated the effect of chronic treatment with rosiglitazone on plasma testosterone levels, steroidogenic response and morphology of Leydig cells in normal rats.

Steroid hormones are synthesized from cholesterol in the gonads in response to pituitary hormones, such as LH/hCG via the classic cAMP/PKA pathway. The main rate-limiting step in the steroidogenenic pathway is the transportation of cholesterol from the outer to inner mitochondrial membrane by a transmembrane protein, StAR protein, the expression and activation of which is maintained by cAMP modulated PKA under maximal stimulation of LH [32].

In the present study, normal rats exposed to rosiglitazone underwent no changes in the level of total plasma testosterone when compared with the controls. A number of authors have reported contrasting results regarding the impact of TZDs on plasma testosterone levels in different clinical and experimental models. In male Zucker diabetic fatty (ZDP) rats, rosiglitazone treatment did not alter plasma testosterone levels $[19,33]$. In healthy men, rosiglitazone decreased testosterone and dihydrotestosterone (DHT) production rates [11]. In women with PCOS and hyperandrogenism, TZD treatment increases sex hormone binding globulin (SHBG) levels in plasma, leading to a decrease in free-circulating testosterone levels [34]. Circulating testosterone is known to be present in three major fractions: free, albumin-bound and sex hormone binding globulin (SHBG) [35]. In contrast to women, men with type 2 diabetes have low testosterone levels and treatment with rosiglitazone induces an increase in the three fractions of circulating testosterone and SHBG levels [36]. As the testosterone measured in the present study represents the total circulating fraction, the measurement of the other two fractions (free and albumin-bound) would be necessary for a better assessment of the effect of rosiglitazone treatment in the present study. However, unlike the human, adult rats do not express SHBG [37]. Additionally, the possibility of decreased clearance rate of testosterone can not be excluded.

In the ex vivo experiments, basal testosterone production was reduced by chronic treatment with rosiglitazone and Leydig cells from rosiglitazone-treated rats were less responsive to cAMP/PKA pathway activation of testosterone production than those from control rats. The ex vivo model is based on the ability of hCG/ 


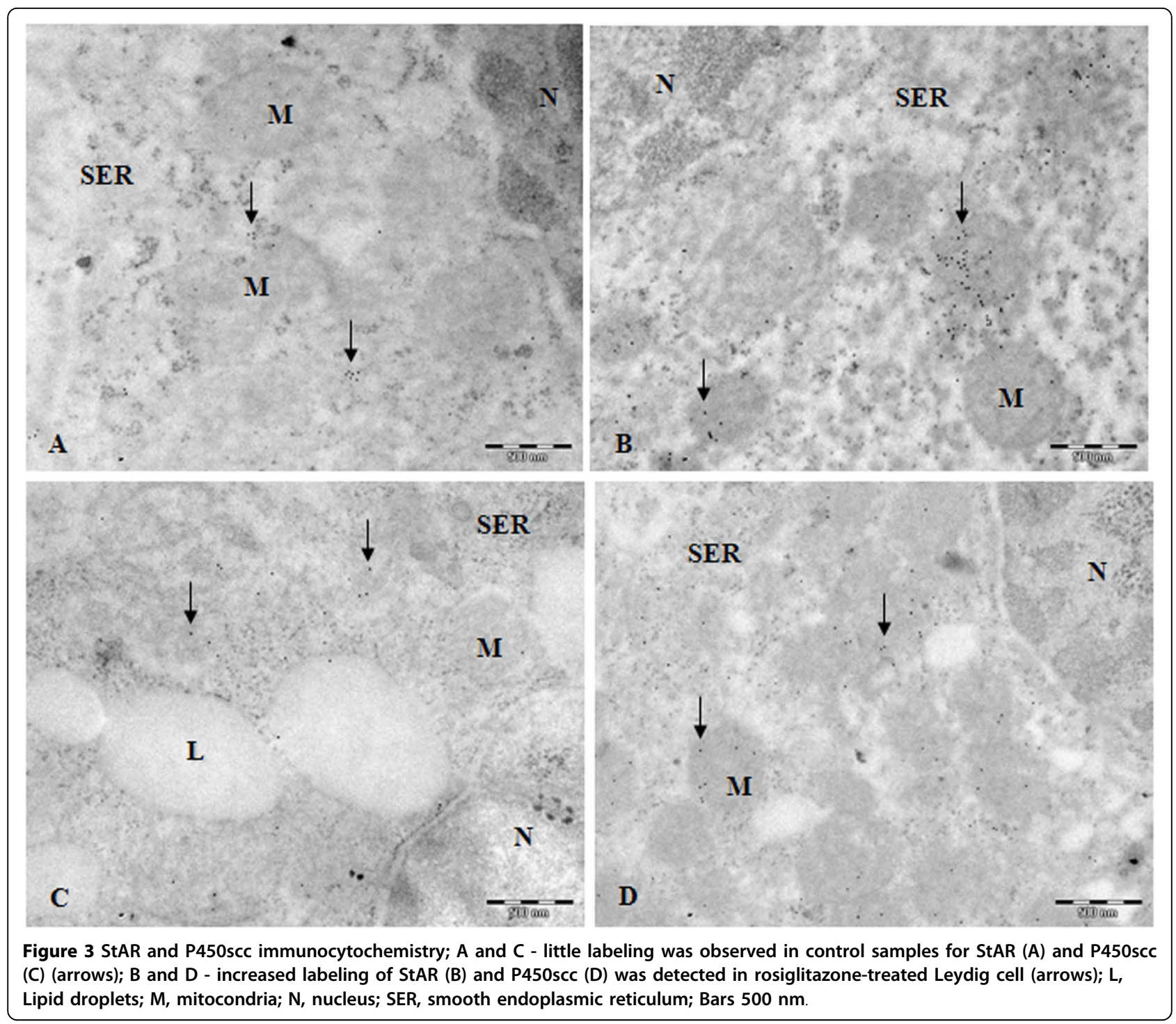

dbcAMP to stimulate testosterone production by Leydig cells in vitro through a mechanism involving PKA activation [26]. The results of the present study suggest a direct effect of rosiglitazone on basal and stimulated testosterone secretion on the PKA level and/or at a point downstream from PKA activation. To further study the earlier steps (before and after mitochondrial P450scc-catalyzed conversion of cholesterol into pregnenolone) of the steroidogenic pathway, 22 (R)-OH-Cinduced and pregnenolone-induced testosterone production was also examined. $22(\mathrm{R})-\mathrm{OH}-\mathrm{C}$ replaces cholesterol because it is membrane-permeable. The high concentrations used were to obviate the interference of any endogenous precursor. When Leydig cells from rosiglitazone-treated rats were challenged with $22(\mathrm{R})$ $\mathrm{OH}-\mathrm{C}$ or pregnenolone, a reduction in testosterone production occurred, indicating that substrate (cholesterol) availability was not affected by the treatment with rosiglitazone, but rather multiple steroidogenic enzymes were limiting.

Morphological analysis of the testis was performed to determine whether the reduced testosterone production in the testes of rosiglitazone-treated rats was due to structural alterations in this tissue or a reduced amount of the proteins involved in the limiting steps of steroidogenesis - StAR and P450scc. Rosiglitazone-treated rats had Leydig cells with activated morphological characteristics, such as vesicular SER, dilated Golgi complexes and few or no lipid droplets. According to Ohata [38], after stimulation with gonadotropin, the inactive tubular SER is converted into vesicles of variable sizes and the author found either hypertrophy or dilatation of the Golgi complexes, which are both related to enhanced secretory cell function. Moreover, activated 


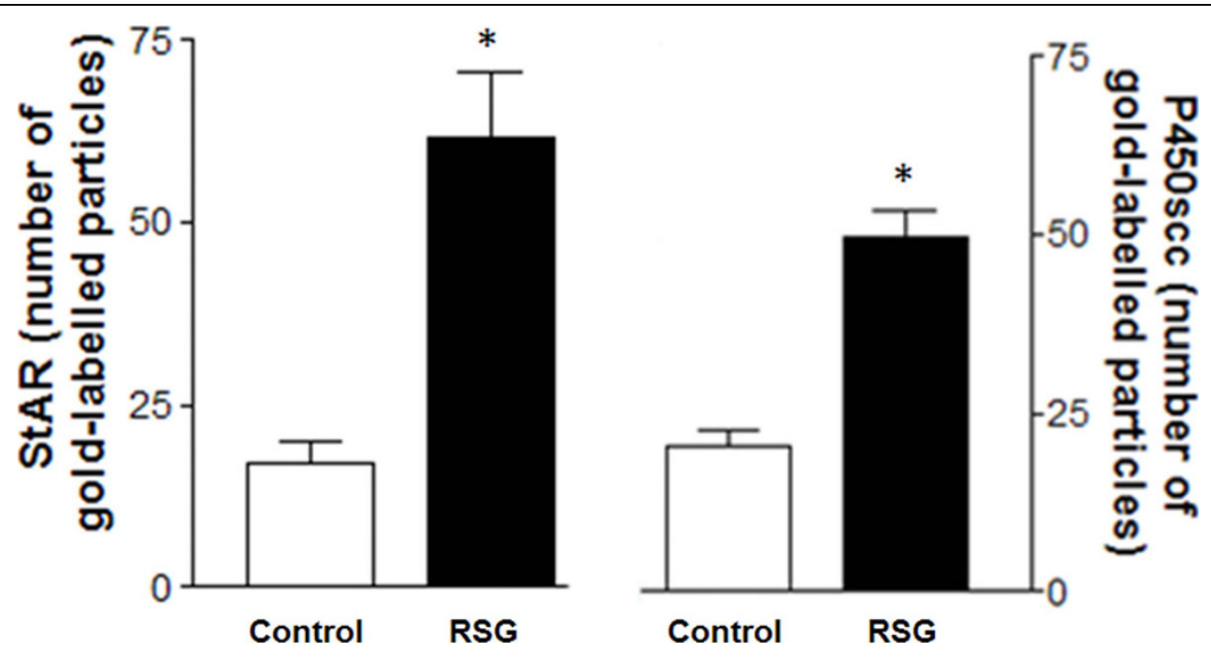

Figure 4 Quantitative analysis of gold-labeled particle distribution in control and rosiglitazone-treated (RSG) Leydig cells; Significant changes were found in treated cells (*Student's $\boldsymbol{t}$ test, $\mathbf{p}<\mathbf{0 . 0 0 0 2}$ ). Mean of gold-labeled particles (mean \pm S.D); $N=10$.

Leydig cells are characterized by few and small lipid droplets, since the cholesterol contained in the droplets is consumed for the synthesis of steroid. In the present study, rosiglitazone-treated Leydig cells exhibited some vacuolated, enlarged mitochondria distributed throughout cytoplasm. This altered mitochondrial morphology could lead to mitochondrial dysfunction. It has been demonstrated in rat and human hepatocytes, that thiazolidinediones cause mitochondrial dysfunction, followed by increased permeability, calcium influx, and nuclear condensation [39]. The order of toxicity by which thiazolidinediones cause mitochondrial dysfunction is troglitazone pioglitazone and rosiglitazone $[40,41]$. Although experimental studies on hepatocytes and isolated mitochondria have indicated that troglitazone but not rosiglitazone or pioglitazone induces mitochondrial dysfunction $[39,40]$, it is possible that the chronic exposure to rosiglitazone, as used in the present study, could lead to mitochondrial damage. It has been proposed by Feinstein et al. (2005) that this effect of thiazolidinediones are PPAR $\gamma$-independent and results from a direct interaction of the drugs with mitochondria, altering bioenergetics and potentially increasing reactive oxygen species production and causing ATP depletion. Recently, the importance of intact mitochondria with active respiration for LH-mediated Leydig cell steroidogenesis has been showed $[41,42]$. These authors showed that maintenance of mitochondrial membrane potencial, mitochondrial ATP synthesis, and mitochondrial $\mathrm{pH}$ are all required for acute steroid biosynthesis. The observed alteration in the state of mitochondria induced by rosiglitazone in our experiments could explain the lower levels of testosterone produced by these cells.

Protein expression levels were evaluated through immunocytochemistry. Leydig cells from rosiglitazonetreated animals exhibited more expressive immunolabelling for StAR and P450scc when compared to control samples. These results are apparently contradictory to the reduced testosterone production by Leydig cells found in the ex vivo experiments. However, studying human ovarian cells in cultures, SetoYoung et al. [43] found that rosiglitazone and pioglitazone stimulated the expression of PPAR $\gamma$, insulin receptor, IRS-1 and StAR, in contrast to results obtained by the authors in a previous report [44], in which thiazolidinediones stimulated progesterone production, but inhibited estradiol and testosterone production in ovarian cells. Recently, other authors found that rosiglitazone stimulated StAR expression but did not affect estradiol and progesterone production by human ovarian cells [45]. The morphological analysis of rosiglitazone-treated testes in the present study revealed important structural damage in the mitochondria of Leydig cells. This alteration could affect (reduce) the function of the StAR and the steroidogenic enzyme P450scc located in the mitochondria, even at high levels of expression of both proteins. It is also possible that other enzymes of the steroidogenic process are affected by rosiglitazone. Previous in vitro studies have demonstrated that thiazolidinediones inhibit the activity of $17 \alpha$-hydroxylase/17,20-lyase $[7,12,14,15]$, which are key enzymes in human androgen synthesis, and aromatase [13]. 
Rosiglitazone is a ligand for PPAR $\gamma$. Recently, the expression of PPAR $\gamma$ has been demonstrated in Leydig cells and an increase in PPAR $\gamma$ mRNA and protein levels has been observed in these cells after chronic treatment with glitazones $[33,46]$. Therefore, it seems reasonable that the expression of StAR and P450scc observed in the present study may be mediated by the nuclear receptor PPAR $\gamma$. However, the mitochondrial damage could indicate that the influence of rosiglitazone on testosterone production could also be PPAR $\gamma$ independent.

\section{Conclusion}

In summary, the present study was designed to examine the effect of chronic treatment with rosiglitazone on the steroidogenic capacity of Leydig cells in normal adult rats. The results revealed that the Leydig cells from rosiglitazone-treated rats showed significant reduction in testosterone production under basal, hCG/dbcAMP- or 22 (R)-OH-C/pregnenolone-induced conditions, although increased labeling of StAR and P450scc was detected in these cells by immunocytochemistry. The ultrastructural study suggested that the lower levels of testosterone produced by these cells could be due to mitochondrial damage induced by rosiglitazone. Further studies are necessary to evaluate the impact of chronic treatment with rosiglitazone on the activity of the StAR and steroidogenic enzymes involved in testosterone production. Although the present study does not permit distinguishing a pituitary gland from the direct effect of rosiglitazone, the observation that this TDZ reduces testosterone production in an ex vivo model indicates that rosiglitazone has direct effects on Leydig cells that are independent of the effects of the drug on the secretion of gonadotropin. Finally, rosiglitazone action in testicular steroidogenesis is potentially of physiological and pathophysiological significance.

\section{Acknowledgements \\ This study was supported by the Universidade Federal de Pernambuco (UFPE), Fundação Oswaldo Cruz (FIOCRUZ), Centro de Tecnologias Estratégicas do Nordeste (CETENE) and Conselho Nacional de Desenvolvimento Científico e Tecnológico (CNPq).}

\section{Author details}

'Department of Morphology and Physiology, Universidade Federal Rural de Pernambuco, Recife, 52.171-900, Brazil. ${ }^{2}$ Ultrastructure Laboratory, Aggeu Magalhães Research Center (FIOCRUZ) and Center for Strategic Technologies of the Northeast (CETENE), Recife, 50.670-901, Brazil. ${ }^{3}$ Department of Antibiotics, Universidade Federal de Pernambuco, Recife, 50.670-901, Brazil. ${ }^{4}$ Department of Physiology and Pharmacology, Universidade Federal de Pernambuco, Recife, 50.670-901, Brazil.

\section{Authors' contributions}

$J A C, C D B, D P U, J S B C V$, MIW carried out the treatment of animals, Leydig cells isolation, radioimmunoassay and performed the statistical analysis. KLAS, CAP carried out the ultrastructural analysis and immunocytochemistry. MIW and CAP conceived of the study, and participated in its design and coordination. MIW, DPU, CAP, KLAS, JAC, CDB, JSBCV, MCL, SLG and IRP participated in the interpretation and analysis of the data and helped to draft the manuscript. All authors read and approved the final manuscript.

\section{Competing interests}

The authors declare that they have no competing interests.

Received: 29 December 2009

Accepted: 9 February 2010 Published: 9 February 2010

\section{References}

1. Inzucchi SE, Maggs DG, Spollett GR, Page SL, Rife FS, Walton V, Shulman GI: Efficacy and metabolic effects of metformin and troglitazone in type II diabetes mellitus. N Engl J Med 1998, 338:867-872.

2. De Leo V, La Marca A, Ditto A, Morgante G, Cianci A: Effects of metformin on gonadotropin-induced ovulation in women with polycystic ovary syndrome. Fertil Steril 1999, 72:282-285.

3. Miyazaki Y, Mahankali A, Matsuda M, Glass L, Mahankali S, Ferrannini E, Cusi K, Mandarino LJ, DeFronzo RA: Improved glycemic control and enhanced insulin sensitivity in type 2 diabetic subjects treated with pioglitazone. Diabetes Care 2001, 24:710-719.

4. Lord JM, Flight IH, Norman RJ: Insulin-sensitising drugs (metformin, troglitazone, rosiglitazone, pioglitazone, D-chiro-inositol for polycystic ovary syndrome. Cochrane Database Syst Ver 2003, 3:CD003053.

5. Sepilian V, Nagamani M: Effects of rosiglitazone in obese women with polycystic ovary syndrome and severe insulin resistance. J Clin Endocrinol Metab 2005, 90:60-65.

6. Freeman DA, Romero A: Effects of troglitazone on cells $\mathrm{n}$ intracellular cholesterol distribution and cholesterol-dependent cell functions in MA10 Leydig tumour cells. Biochem Pharmacol 2003, 66:307-313.

7. Kempná $P$, Hofer $G$, Mullis PE, Flück CE: Pioglitazone inhibits androgen production in NCl-H295R cells by regulating gene expression of CYP17 and HSD3B2. Mol Pharmacol 2007, 71:787-798.

8. Froment P, Gizard F, Defever D, Staels B, Dupont J, Monget P: Peroxisome proliferator-activated receptors in reproductive tissues: from gametogenesis to parturition. J Endocrinol 2006, 189:199-209.

9. Dunaif A, Scott D, Finegood D, Quintana B, Whitcomb R: The insulinsensitizing agent troglitazone improves metabolic and reproductive abnormalities in the polycystic ovary syndrome. J Clin Endocrinol Metab 1996, 81:3299-3306.

10. Bloomgarden ZT, Futterweit W, Poretsky L: Use of insulin-sensitizing agents in patients with polycystic ovary syndrome. Endocr Pract 2001, 7:279-286.

11. Vierhapper H, Nowontny P, Waldhäusl W: Reduced production rates of testosterone and dihydrotestosterone in healthy men treated with rosiglitasone. Metabolism 2003, 52:230-232.

12. Gasic S, Bodenburg Y, Nagamani M, Green A, Urban R: Troglitazone inhibits progesterone production in porcine granulosa cells. Endocrinology 1998, 139:4962-4966.

13. Mu YM, Yanase T, Nishi Y, Waseda N, Oda T, Tanaka A, Takayanagi R, Nawata $\mathrm{H}$ : Isulin sensitizer, troglitazone, directly inhibits aromatase activity in human ovarian granulosa cells. Biochem Biophys Res Commun 2000, 271:710-713.

14. Arlt W, Auchus RJ, Miller WL: Thiazolidinediones but not metformin directly inhibit the steroidogenic enzymes P450c and 3 $\beta$-hydroxysteroid dehydrogenase. J Biol Chem 2001, 276:16767-16771.

15. Gasic S, Nagamani M, Green A, Urban RJ: Troglitazone is a competitive inhibitor of $3 \beta$-hydroxysteroid dehydrogenase enzyme in the ovary. Am J Obst Ginecol 2001, 184:575-579.

16. Schoppee PD, Garmey JC, Valdhuis J: Putative activaction of the peroxixome proliferator-activated receptor $\gamma$ impairs androgen and enhances progesterone biosynthesis in primary cultures of porcine theca cells. Biol Reprod 2002, 66:190-198.

17. Veldhuis JD, Zhang G, Garmey JC: Troglitazone, an insulin-sensitizing thiazolidinedione, represses combined stimulation by $\mathrm{LH}$ and insulin of de novo androgen biosynthesis by thecal cells in vitro. $J$ Clin Endocrinol Metab 2002, 87:1129-1133.

18. Rubin GL, Duong JH, Clyne CD, Speed CJ, Murata Y, Gong C, Simpson ER: Ligands for the peroxisomal proliferator-activated receptor $\gamma$ and the retinoid $\times$ receptor inhibit aromatase cytochrome P450 (CYP19) 
expression mediated by promoter II in human breast adipose. Endocrinology 2002, 143:2863-2871.

19. Fürnsinn C, Nowotny B, Brunmair B, Gras F, Roden M, Waldhäusl W, Vierhapper $\mathrm{H}$ : Thiazolidinediones influence plasma steroides of male obese Zucker rats. Endocrinology 2002, 143:327-330.

20. Minge CE, Robker RL, Norman RJ: PPAR gamma coordinating metabolic and immune contributions to female fertility. PPAR Res 2008, Article ID 243791.

21. Wanderley MI, Negro-Vilar A: Pretreatment with phorbol ester and LHRH agonist reduces testosterone production and protein kinase $\mathrm{C}$ activity in rat Leydig cells challenged with PDBu and LHRH. Braz J Med Biol Res 1996, 29:1557-65.

22. Weng Q, Medan MS, Watanabe G, Tsubota T, Tanioka Y, Taya K: Immunolocalization of steroidogenic enzymes P450scc, 3BHSD, P450c17, and P450arom in Göttingen miniature pig testes. J Reprod Dev 2005, 51:299-304.

23. Saraiva KLA, Silva Junior VA, Dias ESF, Peixoto CA: Morphological changes in the testis induced by diethylcarbamazine. Reprod Toxicol 2006, 22:754-759.

24. Peixoto CA, Norões J, Rocha A, Dreyer G: Immunocytochemical localization and distribution of human albumin in Wuchereria bancrofti adult worms. Arch Pathol Lab Med 1999, 123:173-177.

25. Niswender GD, Akbar AM, Nett TM: Use of specific antibodies for quantification of steroid hormones. Methods in Enzymology. Vol Part A XXXVI New York: Academic PressO'Malley BW, Hardman JG 1975, 16.

26. Dehejia A, Nozu K, Catt KJ, Dufau ML: Luteinizing hormone receptors and gonadotropic activation of purified rat Leydig cells. J Biol Chem 1982, 257:13781-86.

27. Houseknecht KL, Cole BM, Steele PJ: Peroxisome proliferator-activated receptor gamma (PPAR gamma) and its ligands: a review. Domest Anim Endocrinol 2002, 22:1-23.

28. Gurnell M, Savage DB, Chatterjee VK, O'Rahilly S: The metabolic syndrome: peroxisome proliferator-activated receptor gamma and its therapeutic modulation. J Clin Encocrinol Metab 2003, 88:2412-2421.

29. Staels B, Fruchart JC: Therapeutic roles of peroxisome proliferatoractivated receptor agonists. Diabetes 2005, 54:2460-2470.

30. Kalaitzidis RG, Sarafidis PA, Bakris GL: Effects of thiazolidinediones beyond glycaemic control. Curr Pharm Des 2009, 15:529-536.

31. Azziz R, Ehrmann D, Legro RS, Whitcomb RW, Hanley R, Fereshetian AG, O'Keefe M, Ghazzi MN: Troglitazone improves ovulation and hirsutism in the polycystic ovary syndrome: a multicenter, double blind, placebocontrolled trial. J Clin Endocrinol Metab 2001, 86:1626-1632.

32. Stocco DM, Clark BJ: The role of the steroidogenic acute regulatory protein in steroidogenesis. Steroids 1997, 62:29-36.

33. Mansour M, Coleman E, Dennis J, Akingbemi B, Ashwartz D, Braden T, Judd R, Plaisance E, Ken Stuart L, Morrison E: Activation of PPAR by rosiglitazone does not negatively impact male sex steroid hormones in diabetic rats. PPAR Res 2009, 101857, doi: 10.1155/2009/101857.

34. Brettenthaler N, De Geyter C, Huber PR, Keller U: Effect of the insulin sensitizer pioglitazone on insulin resistance, hyperandrogenism, and ovulatory dysfunction in women with polycystic ovary syndrome. J Clin Endocrinol Metab 2004, 89:3835-3840.

35. Kapoor D, Malkin CJ, Channer KS, Jones TH: Androgens, insulin resistance and vascular disease in men. Clin Endocrinol (Oxf) 2005, 63:239-250

36. Kapoor D, Channer KS, Jones TH: Rosiglitazone increases bioactive testosterone and reduces waist circumference in hypogonadal men with type 2 diabetes. Diabetes Vasc Dis Res 2008, 5:135-137.

37. Reventos J, Sullivan PM, Joseph DR, Gordon JW: Tissue-specific expression of the rat androgen-binding protein/sex hormone-binding globulin gene in transgenic mice. Mol Cell Endocrinol 1993, 96:69-73.

38. Ohata M: Electron microscopy study on the testicular interstitial cells in the mouse. Arch Histol Jpn 1979, 42:51-79.

39. Feinstein DL, Spagnolo A, Akar C, Weinberg G, Murphy P, Gavrilyuk V, Dello Russo C: Receptor-independent actions of PPAR thiazolidinedione agonists: is mitochondrial function the key?. Biochem Pharmacol 2005, 70:177-188.

40. Masubuchi Y: Metabolic and non-metabolic factors determining troglitazone hepatotoxicity: a review. Drug Metab Pharmacokinet 2006, 21:347-356.
41. Allen JA, Shankara $T$, Janus $P$, Buck $S$, Diemer $T$, Hales KH, Hales DB: Energized, polarized, and actively respiring mitochondria are required for acute Leydig cell steroidogenesis. Endocrinology 2006, 147:3924-3935.

42. Midzak AS, Liu J, Zirkin BR, Chen H: Effects of myxothiazol on Leydig cell steroidogenesis: inhibition of luteinizing hormone-mediated testosterone synyhesis but stimulation of basal steroidogenesis. Endocrinology 2007, 148:2583-2590

43. Seto-Young D, Avtanski D, Strizhevsky M, Parikh G, Patel P, Kaplun J, Holcomb K, Rosenwaks Z, Poretsky L: Interactions among peroxisome proliferator activated receptor- $\gamma$, insulin signaling pathways, and steroidogenic acute regulatory protein in human ovarian cells. $J$ Clin Endocrinol Metab 2007, 92:2232-2239.

44. Seto-Young D, Paliou M, Schlosser J, Avtanski D, Park A, Patel P, Holcomb K, Chang P, Poretsky L: Direct thiazolidinedione action in the human ovary: insulin-independent and insulin-sensitizing effects on steroidigenesis and insulin-like growth factor binding protein-1 production. J Clin Endocrinol Metab 2005, 90:6099-6105.

45. Chen Q, Sun X, Chen J, Cheng L, Wang J, Wang Y, Sun Z: Direct rosiglitazone action on steroidogenesis and proinflammatory factor production in human granulosa-lutein cells. Reprod Biol Endocrinol 2009, 7:147

46. Kowalewski MP, Dyson MT, Manna PR, Stocco DM: Involvement of peroxisome proliferator-activated receptor $\gamma$ in gonadal steroidogenesis and steroidogenic acute regulatory protein expression. Reprod Fertil Dev 2009, 21:909-922.

doi:10.1186/1477-7827-8-13

Cite this article as: Couto et al:: Effect of chronic treatment with

Rosiglitazone on Leydig cell steroidogenesis in rats: In vivo and ex vivo studies. Reproductive Biology and Endocrinology 2010 8:13.

\section{Submit your next manuscript to BioMed Central and take full advantage of:}

- Convenient online submission

- Thorough peer review

- No space constraints or color figure charges

- Immediate publication on acceptance

- Inclusion in PubMed, CAS, Scopus and Google Scholar

- Research which is freely available for redistribution

Submit your manuscript at www.biomedcentral.com/submit
C Biomed Central 